Article

\title{
The Effect of Formal and Informal External Collaboration on Innovation Performance of SMEs: Evidence from China
}

\author{
Chang $\mathrm{Lu}$ and Bo Yu * \\ School of Management, Harbin Institute of Technology, Harbin 150001, China; luchang93@hit.edu.cn \\ * Correspondence: yub@hit.edu.cn
}

Received: 28 September 2020; Accepted: 17 November 2020; Published: 18 November 2020

\begin{abstract}
External collaboration is an effective way for small and medium-sized enterprises (SMEs) to improve innovation performance and obtain sustainable competitiveness. This study focuses on the influence of external collaboration on innovation performance of SMEs. Specifically, this study classifies external collaboration into formal and informal external collaboration, and explores their different impacts on innovation performance of SMEs, respectively. Moreover, this study examines the moderating effects of managers' entrepreneurial orientation and organizational legitimacy on the relationships between formal and informal collaboration and innovation performance of SMEs. Survey data from 213 high-tech manufacturing SMEs in China reveals that: (1) Both formal and informal external collaboration have positive effects on innovation performance of SMEs, and informal external collaboration offers greater benefits than formal external collaboration; (2) managers' entrepreneurial orientation positively moderates the relationship between informal external collaboration and SMEs' innovation performance; (3) organizational legitimacy positively moderates the relationships between formal and informal external collaboration and SMEs' innovation performance. This study enriches the research on the relationship between external collaboration and innovation performance of SMEs, and advances the understanding of the contextual factors between formal and informal external collaboration-SMEs' innovation performance relationships through elucidating the moderating role of managers' entrepreneurial orientation and organizational legitimacy.
\end{abstract}

Keywords: formal external collaboration; informal external collaboration; innovation performance; managers' entrepreneurial orientation; organizational legitimacy; SMEs

\section{Introduction}

Continuous innovation is vital for enterprises to acquire sustained competitiveness. However, in recent years, innovation has become increasingly complex, costly, and risky because of changing customer demands, fierce market competition, and rapid technological changes [1]. It has been difficult for a single firm, especially a small and medium-sized enterprise (SME), for which resources and technologies are relatively deficient, to achieve successful innovation alone [2,3]. Therefore, to overcome these challenges and improve innovation performance, more and more firms have started shifting to open innovation strategy and strengthening external collaboration with external partners to leverage external resources [4,5]. External collaboration is an effective way to help firms acquire useful knowledge and technologies, reduce the costs and risks in the process of innovation, enhance the efficiency of innovation, and then improve innovation performance [6,7].

The relationship between external collaboration and firms' innovation performance has increasingly received attention in scientific research, but so far, few of the existing studies have classified external collaboration into formal and informal external collaboration and explored their 
different impacts on firms' innovation performance. The existing literature has mainly focused on the breadth and depth of external collaboration [8,9], intra- and inter-regional external collaboration [10,11], and academic and industrial collaboration [12,13]. However, in fact, formal and informal external collaboration are very common in firms' practice, and both types of external collaboration are very significant for firms' innovation outcomes [14,15]. Additionally, some studies have shown that the impacts of formal and informal collaboration modes on firms' innovation outcome are different [16]. In addition, existing studies on open innovation and external collaboration have mainly focused on large firms, and little attention has been paid to SMEs [17]. However, because of the scarcity of resources and technologies, SMEs are more dependent on external collaboration than large firms [3], and due to the differences in firms' structure and features, the effect of external collaboration on innovation performance may also be different among SMEs and large firms [18]. Therefore, classifying external collaboration into formal and informal external collaboration and examining their different impacts on innovation performance of SMEs is crucial.

Moreover, the effectiveness of formal and informal external collaboration varies in different firms; therefore, can the effectiveness of formal and informal external collaboration be affected by other factors? Most of the existing research on the relationship between external collaboration and innovation performance has neglected the role of individual level factors and ignored the "human side" [19]. However, the leadership trait theory pointed out that a firm's strategic decisions and performance are greatly affected by the manager's characteristics and preference $[20,21]$, and this phenomenon is more obvious in SMEs, in which power is centralized [22]. Santoro et al. found that the characteristics of managers in SMEs can affect firms' proclivity towards openness and external collaboration, and influence SMEs' innovation performance [23]. Managers' entrepreneurial orientation is an important factor that reflects the characteristics of managers, and most of the existing research only regarded it as the antecedent of firms' performance and examined its direct effect on firms' performance [24]; however, little is known about its potential moderating effect on the relationship between external collaboration and firms' innovation performance.

In addition, existing studies on the relationship between external collaboration and innovation performance have also neglected the role of organizational legitimacy. Organizational legitimacy reflects the extent to which an organization is approved and accepted by external stakeholders [25], and it is very helpful for firms, especially for SMEs, for which credit and social approval degree are relatively low, to benefit from external collaboration [26]. Tsinopoulos et al. indicated that as the level of a firm's motivation to achieve legitimacy increases, the effectiveness of its external collaboration is also likely to increase [27]. Thus, we can infer that the impact of external collaboration on firms' innovation performance will become more significant when firms' organizational legitimacy increases. However, few empirical studies have put organizational legitimacy into the research framework of external collaboration and explored its potential moderating effect on the relationship between external collaboration and firms' innovation performance.

Therefore, considering the above, this research seeks to answer the following research questions: (1) What are the effects of formal and informal external collaboration on the innovation performance of SMEs, and what are the differences between these effects? (2) Do managers' entrepreneurial orientation and organizational legitimacy have moderating effects on the relationships between formal and informal external collaboration and innovation performance of SMEs? To solve these research questions, this study developed a theoretical model based on the existing research, and conducted empirical research on a sample of 213 high-tech manufacturing SMEs in China. Data were collected through questionnaires, and hierarchical regression analysis method was used for empirical research. The findings indicate that: (1) Both formal and informal external collaboration have positive effects on SMEs' innovation performance, and informal external collaboration has a stronger impact on SMEs' innovation performance than formal external collaboration; (2) managers' entrepreneurial orientation strengthens the positive effect of informal external collaboration on innovation performance 
of SMEs; (3) organizational legitimacy strengthens the positive effects of formal and informal external collaboration on innovation performance of SMEs.

This study contributes to the theory and practice in three ways. First, this study extends the literature on external collaboration and innovation performance by classifying external collaboration into formal and informal external collaboration and offering quantitative empirical analyses of their different impacts on innovation performance of SMEs. Second, this study further extends the external collaboration-innovation performance literature by highlighting the unique role of managers' entrepreneurial orientation and organizational legitimacy as contingency factors that can enhance the relationship between formal/informal external collaboration and innovation performance of SMEs. Third, this study focuses on SMEs' external collaboration, and it is helpful to fill the research gap where little is known about open innovation in the context of SMEs. Besides, the results of this study can offer some practical guidance to SMEs to enhance their innovation performance via external collaboration. This study suggests that to improve innovation performance, SMEs should strengthen formal and informal external collaboration with external organizations, especially informal external collaboration. At the same time, to amplify the positive effects of formal and informal external collaboration, SMEs should take some measures to enhance their managers' entrepreneurial orientation and organizational legitimacy. The rest of this study is organized as follows. Section 2 presents a review of relevant literature and establishes the hypotheses. Section 3 describes the materials and methods to test the hypotheses. Section 4 shows the results of hypotheses testing. In Section 5, we discuss the findings and research conclusions, offer the theoretical and practical implications, and conclude limitations and provide directions for future research.

\section{Literature Review and Hypotheses Development}

\subsection{External Collaboration}

In today's increasingly complex and knowledge-intensive world with shortened product life cycles and intensified competition, it is increasingly difficult for a single firm to internalize innovations, especially for an SME, for which resources and capabilities are limited [1-3]. As a result, more and more firms begin to cross organizational boundaries and participate in external collaboration. Interorganizational external collaboration, which can facilitate the flows of resources and technologies in different organizations, has emerged as an important way for firms' innovation. [16,28]. Participating in such external collaboration activities provides firms with opportunities to acquire various resources, ideas, and technologies [29]. Besides, it can also help firms to share the costs of innovation with their partners and reduce the uncertainty in the process of innovation [30]. Therefore, for firms, especially for SMEs, external collaboration is very important for improving their innovation performance [31]. In recent years, external collaboration has become a heavily researched topic in the field of innovation management and strategic management.

External collaboration is an important form of open innovation strategy, and it mainly refers to the behavior of firms to cross organizational boundaries and build collaboration relationships with external organizations such as suppliers, customers, competitors, and universities [28]. Studies on external collaboration are grounded on three primary theories or perspectives. First, from the knowledge-based view, external collaboration is helpful to acquire knowledge that does not exist in the firm, such as specialized technological knowledge, market information, and customer needs [32]. External collaboration thus extends firms' knowledge base, which is crucial for innovation. Second, from the perspective of cost and risks, external collaboration can help reduce costs and risks through co-R\&D and building shared expectations and approaches to challenges in the process of innovation [30]. Third, from the perspective of organizational learning, external collaboration can help firms to learn skills and competences related to the technology and market aspects underlying the innovation [9]. Among numerous studies on external collaboration, the relationship between external collaboration and firms' innovation performance has attracted many researchers' attention. 
However, researchers have not reached a consensus on the relationship between external collaboration and firms' innovation performance. Some scholars argued that external collaboration has a positive effect on innovation performance [33], whereas a considerable number of studies indicated that there is an inverted-U relationship between external collaboration and innovation performance [34]. For these contradictory findings, many researchers think the reason is that most of the previous studies regarded external collaboration as a one-dimension concept and neglected the fact that there are many classifications of external collaboration. Therefore, many researchers have begun to classify external collaboration into breadth and depth of collaboration [8,9], intra- and inter-regional external collaboration [10,11], and academic and industrial collaboration [12,13], and then explored their effects on innovation performance. However, few of them have paid attention to the formal and informal dimension of external collaboration. In fact, formal and informal external collaboration are very common in firms' practice, and some studies have indicated that these two types of external collaboration have different impacts on innovation performance [16]. In addition, the contingency factors in the relationship between external collaboration and innovation performance has also attracted scholars' attention. However, existing studies have mainly focused on the contingency role of external factors, such as technological uncertainty [35] and government support [36], and internal competency factors such as absorptive capacity [16]. Many other important potential contingency factors, such as managers' entrepreneurial orientation and organizational legitimacy, have not been examined. Finally, studies on external collaboration and innovation performance have mainly focused on large firms and ignored the SMEs [17]. However, the role of external collaboration is different in large firms and SMEs, and it is necessary to explore the relationship between external collaboration and innovation performance in the context of SMEs. Therefore, exploring the effect of formal and informal external collaboration on innovation performance of SMEs and examining the moderating effects of managers' entrepreneurial orientation and organizational legitimacy on the above relationships are necessary and significant.

\subsection{Hypotheses}

\subsubsection{Formal External Collaboration and Innovation Performance of SMEs}

Formal external collaboration refers to the collaborative relationships based on contracts, formal agreements, and formal transactions between firms and their external partners [16]. The main forms of formal external collaboration include collaboration based on contracts between the focal firm and its partners, venture investment, joint ventures, mergers and acquisitions, technology licensing, and patent purchase $[37,38]$. We suggest that formal external collaboration has a positive impact on innovation performance of SMEs. First, from the knowledge-based view, formal external collaboration can broaden SMEs' knowledge base. It helps SMEs keep formal and stable collaborative relationships with external sources, and SMEs can acquire a lot of complementary knowledge and resources through these collaborative relationships [32]. Therefore, through formal external collaboration with outside organizations, both the amount and diversity of knowledge owned by SMEs can be increased, and SMEs' knowledge base can become more abundant [39]. An abundant knowledge base can promote the integration of external knowledge, the creation of new ideas, and then it can enhance SMEs' innovation performance $[13,40]$. Besides, SMEs with a broad knowledge base tend to be more sensitive towards external market opportunities. When faced with a dynamic market environment, SMEs with a broad knowledge base are more likely to perceive and seize new business opportunities, and achieve radical innovation [41].

Moreover, establishing formal external collaboration relationships with external partners helps SMEs reduce $R \& D$ expenditure, decrease the costs and risks of innovation, enhance innovation efficiency, and finally promote the improvement of innovation performance. Innovation activities usually need a lot of inputs such as capital and human resources; however, the uncertainty and failure rate of innovation is high. Therefore, the costs and risks of innovation is too high for SMEs to 
undertake [42]. When SMEs implement formal external collaboration, they can share human resources and equipment with their partners and develop new products together with their partners, which would thereby reduce the R\&D expenditure and the costs of innovation [8,43]. Besides, having various external partners allow firms to capture market demand correctly and have a good command of the development trends of the market and technology, which can reduce the risks of failure and decrease the uncertainty related to the innovation [44]. The decline of costs and risks of innovation is beneficial to improving innovation efficiency, and then enhancing innovation performance of SMEs. Therefore, we therefore hypothesize:

Hypothesis 1 (H1). Formal external collaboration has a positive impact on the innovation performance of SMEs.

\subsubsection{Informal External Collaboration and Innovation Performance of SMEs}

Informal external collaboration refers to the collaborative relationships based on personal networks rather than legally binding contracts [45]. In the process of informal external collaboration, firms source knowledge from external partners based on non-contractual relationships [46,47]. Firms can implement informal external collaboration by participating in trade fairs, conferences, seminars, and social activities, having frequent informal communication with individuals in other organizations, and sharing facilities with other organizations [48]. We argue that informal external collaboration also has a positive impact on innovation performance of SMEs, and it offers greater benefits than formal external collaboration. First, participating in informal external collaboration is an effective way to obtain tacit knowledge. Instead of explicit knowledge such as patents and operating procedures, tacit knowledge is also very important for firms' innovation [49]. However, tacit knowledge is non-codified and disembodied knowledge, and it is difficult for individuals and firms to understand and transfer [50]. Tacit knowledge cannot be transmitted in the form of reports and statements, and it only could be acquired through close interactions with external partners [51,52]. The building of informal external collaboration relationships enhances the opportunities for SMEs to contact and communicate closely with their partners. Through the frequent contact and dialogue among individuals of different firms, people can share their feelings and experiences through face-to-face contacts, and tacit knowledge is more likely to be converted into shared terms and concepts, and then obtained by other firms [52].

Besides, from a trust perspective, frequent and close informal external collaboration can cultivate mutual trust between the SME and its external partners. Crescenzi et al. stated that through participating in informal collaboration activities such as seminars and conferences frequently, the firm and its partners can have a deep understanding of each other's opinions, behaviors, and values, thus enhancing the mutual trust between them [53]. Martin et al. suggested that the SME's deep informal collaboration with its partners is beneficial to the formation of positive expectation of each other's behavior and the increase the mutual trust [54]. Mutual trust increases partners' willingness to share their successful experience of innovation and exchange important resources with the SME, thereby speeding up the SME's innovation process and improving its innovation performance [55].

Moreover, from a cost perspective, informal external collaboration provides SMEs with crucial knowledge and resources at a lower cost, which in turn reduce the costs of innovation and enhance the efficiency of innovation. Informal external collaboration activities mainly rely on individual's social ties and do not require much investment [56]. For example, SMEs' researchers can obtain inspiration and suggestion about new products development through chatting with researchers in other organizations. Besides, managers in SMEs can acquire innovation experience from CEOs of other firms through participating in seminars, thereby adjusting the strategy of innovation development timely and enhancing SMEs' innovation performance [42,57]. Therefore, informal external collaboration decreases the costs of external searching, and is very crucial to enhance innovation efficiency and improve the innovation performance of SMEs. 
In addition, for SMEs, informal external collaboration is more beneficial for the improvements of innovation performance than formal external collaboration. The building of informal external collaboration can avoid contracting costs, management costs, transaction costs, and monitoring costs that exist in the process of building formal external collaboration relationships [2,58]. Moreover, informal external collaboration can provide SMEs with a quick and flexible way to benefit from outside sources to improve innovation performance [16]. Besides, due to the low credit and high level of uncertainty, it is difficult for SMEs to establish formal collaboration with large firms which have advanced technologies. Even if a formal collaboration relationship is established, it is still hard for SMEs to acquire core knowledge from large firms because of the restriction of contracts. However, in the process of informal communication and contacts, external partners tend to disclose important pieces of knowledge, ideas, and information unintentionally [42,59], which can be the keys for SMEs' innovation. Therefore, compared with formal external collaboration, SMEs benefit more from informal external collaboration, because of the lower costs, quicker and more flexible knowledge acquirement modes, and greater possibility of acquiring core knowledge. As a result, we hypothesize:

Hypothesis 2 (H2). Informal external collaboration has a positive impact on innovation performance of SMEs, and it is more beneficial for the improvements of SMEs' innovation performance than formal external collaboration.

\subsubsection{The Moderating Effect of Managers' Entrepreneurial Orientation}

Entrepreneurial orientation is firstly viewed as a firm-level concept, and it is defined as a firm's proclivity towards innovative, risk-taking, and proactive activities $[60,61]$. In recent years, many studies have studied the entrepreneurial orientation at the individual-level and focused on managers' entrepreneurial orientation [62,63]. Managers' entrepreneurial orientation reflects the attitude of a manager to engage in innovative, risk-taking, and proactive behaviors. As this study focus on SMEs, which are very centralized, and managers' preferences and characteristics usually have great impacts on SMEs' strategies and performance; therefore, this research regards entrepreneurial orientation as an individual-level construct and focuses on managers' entrepreneurial orientation.

The existing literature has shown that managers' entrepreneurial orientation includes three dimensions: Innovativeness, risk-taking, and proactiveness. Innovativeness refers to the propensity of a manager to create new goods or service, introduce new technologies, and enter new markets. Risk-taking reflects the extent to which a manager's willingness to take business-related risks, such as committing significant resources when the outcome is highly uncertain. Finally, proactiveness refers to the inclination of a manager to come up with "proactive" innovations such as introducing new products ahead of its competitors [63].

Managers' entrepreneurial orientation strengthens the positive effects of formal and informal external collaboration on the innovation performance of SMEs. First, from the dimension of innovativeness, SME managers who value innovation can increase SMEs' intention to collaborate. SME managers with high innovativeness tend to force the SMEs to innovate constantly. Innovation requires a lot of resources, and in order to obtain more resources, the SMEs must become more active to collaborate with external sources, and this positive attitude can enhance the effectiveness of external collaboration [64]. In addition, a SME with innovative managers tends to enhance the internal R\&D investment, which can improve the absorptive capacity. Strong absorptive capacity enhances SME's assimilation of external knowledge and promotes the transfer of external knowledge [65]. Therefore, when a manager's tendency to innovate is high, SME's intention to collaborate can be increased and its absorptive capacity can be enhanced, thus improving the efficiency of external collaboration, and amplifying the positive effect of external collaboration on innovation performance of SMEs. Second, from the dimension of risk-taking, a SME's manager with a high risk-taking preference tends to encourage the SME to invest more resources into collaboration activities even when the uncertainty is high [66]. High investment can improve the efficiency and the effectiveness of external 
collaboration. Besides, a manager who can undertake the risks of collaboration can improve the stability of external collaboration relationships. Stable external collaboration relationships can facilitate the flow of knowledge among forms within the networks, and then strengthen the benefits of external collaboration on the innovation performance of SMEs [6]. Third, from the dimension of proactiveness, SMEs' managers with a high level of proactiveness tend to require the firms to engage in proactive and extensive external scanning in the process of external collaboration, because they always want to be the first to produce new products in the market. Proactive and extensive external scanning enhances the possibility for firms to obtain useful information and find new market opportunity from external partners, thereby improving the positive effect of external collaboration on the innovation performance of SMEs [67].

In summary, managers' entrepreneurial orientation could amplify the benefits of external collaboration on innovation performance of SMEs by raising enthusiasm for external collaboration, enhancing absorptive capability, increasing resource investment, enhancing the stability of external collaboration relationships, and increasing proactive and extensive external scanning. Thus,

Hypothesis 3a (H3a). Managers' entrepreneurial orientation positively moderates the relationship between formal external collaboration and innovation performance of SMEs.

Hypothesis $3 \mathbf{b}(\mathbf{H} 3 \mathbf{b})$. Managers' entrepreneurial orientation positively moderates the relationship between informal external collaboration and innovation performance of SMEs.

\subsubsection{The Moderating Effect of Organizational Legitimacy}

Organizational legitimacy reflects the extent to which an organization is approved and accepted by their stakeholders, and it is defined as "a generalized perception or assumption that the actions of an entity are desirable, or appropriate within some socially constructed system of norms, values, beliefs, and definitions" $[25,68]$. Due to the low credit and high uncertainty, SMEs usually face many difficulties when participating in external collaboration [26,69]. For example, many external organizations are reluctant to collaborate with SMEs, therefore, compared with large firms, SMEs need to spend more effort and resources in building collaboration relationships with external sources. Besides, after building external collaboration relationships, it is difficult for SMEs to gain trust from their external partners, thereby decreasing the effectiveness of external collaboration. Gaining organizational legitimacy can help SMEs overcome these obstacles effectively. Some studies indicated that organizational legitimacy is an important strategic resource for SMEs, and it is helpful for SMEs to gain support and trust from external stakeholders, and then benefit more from open innovation [70].

Organizational legitimacy strengthens the positive effects of formal and informal external collaboration on the innovation performance of SMEs. First, high organizational legitimacy reduces the costs of establishing external collaboration, and improves the efficiency of external collaboration. SMEs usually need to spend a lot of time and effort to find collaborators. High organizational legitimacy can increase the reputation and reliability of SMEs, and it can help SMEs attract external partners easily [71]. Therefore, when the organizational legitimacy of SMEs is high, costs related to finding partners can be reduced, and the positive impact of external collaboration can be amplified. Besides, when a SME's behaviors meet relevant laws and regulations set by the government, it is more likely to gain institutional support from the government, thereby reducing the funding pressure and transaction costs in the process of collaboration and increasing the efficiency of external collaboration [72]. Second, high organizational legitimacy helps SMEs gain trust from their collaborators and then enhances the possibility to acquire critical resources they need. When a SME is perceived as legitimate, it indicates that this SME is trustworthy and is more likely to avoid opportunistic behavior, and it is helpful for the SME to obtain trust from their collaborators [73]. Trust improves the willingness of collaborators to share their critical resources with the SME and facilitates the flow of knowledge among the SME and 
its partners, thereby increasing the possibility for this SME to acquire external critical resources and enhancing the positive effect of external collaboration on the SME's innovation performance $[55,74]$. Third, high organizational legitimacy enhances employees' loyalty, and then improves SMEs' efficiency of resource integration. SMEs with higher organizational legitimacy can gain much approval and support from the employees, and then the loyalty of employees can be enhanced [75]. When the employees are loyal to the SMEs they serve, they tend to invest more effort to absorb and integrate new resources, and SMEs' efficiency to resource absorption and integration can be enhanced. High resource absorption and integration efficiency are helpful for SMEs to benefit more from external collaboration.

To summarize, organizational legitimacy could augment the positive effect of external collaboration on innovation performance of SMEs by reducing costs, gaining trust, and enhancing employees' loyalty. Thus,

Hypothesis 4a (H4a). Organizational legitimacy positively moderates the relationship between formal external collaboration and innovation performance of SMEs.

Hypothesis $\mathbf{4 b} \mathbf{b} \mathbf{H} 4 \mathbf{b})$. Organizational legitimacy positively moderates the relationship between informal external collaboration and innovation performance of SMEs.

The theoretical model of this study is summarized in Figure 1.

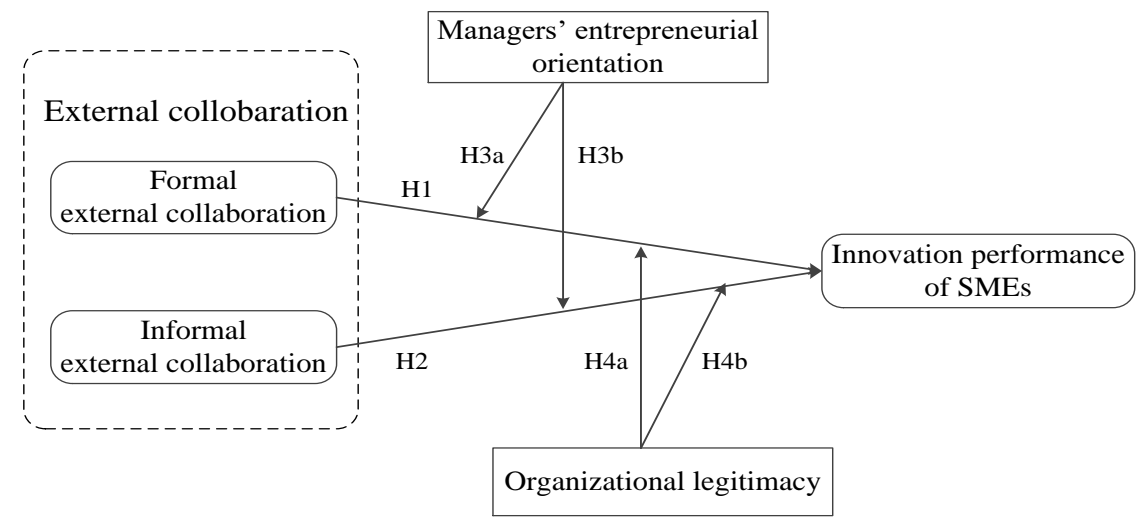

Figure 1. Theoretical model.

\section{Materials and Methods}

\subsection{Procedure and Sample}

This study was carried out on a sample of high-tech manufacturing SMEs in China, and the data was collected through questionnaires. In recent years, the Chinese government pays much attention to the development of SMEs, and SMEs in China have developed very fast. In order to succeed in the market competition, more and more SMEs in China are implementing open innovation strategies and participating in formal and informal external collaboration activities. Moreover, among SMEs, high-tech manufacturing SMEs are more active to engage in external collaboration than other types of firms. Therefore, in this study, we chose high-tech manufacturing SMEs in China as our research sample [36]. In China, for industrial enterprises, SMEs are defined as firms with less than 1000 employees, or firms for which total revenue is less than 400 million Chinese Yuan. We developed the questionnaire following the three steps. First, we conducted in-depth interviews with three managers from different high-tech manufacturing SMEs, and collected firsthand information of the SMEs' formal and informal external collaboration. Second, based on the information obtained through interviews and existing high-level literatures, we developed a questionnaire in English, which was then translated into Chinese by two Chinese Ph.D. candidates majored in management who are fluent in both languages. To guarantee accuracy, the Chinese version questionnaire was then back translated into English by two 
professional translators. Third, we selected 15 high-tech manufacturing SMEs in China and conducted a pilot test with 15 managers from these SMEs. Based on the pilot test results, we improved the questionnaire again and then finalized it.

Our sample are high-tech manufacturing SMEs located in Northern China, and most of them are located in Heilongjiang province, Liaoning province, Beijing, and Shandong province. The industrial foundation of these areas is very solid, and local governments of these areas strongly support the development of high-tech industries. Under this circumstance, high-tech manufacturing SMEs in these areas develop very fast, and the number of them is very large. All the high-tech manufacturing SMEs must meet the following three requirements. First, the firms conduct high-tech product manufacturing activities. Second, the firms engage in product innovation activities. Third, the firms have participated in external collaboration activities in recent years. In order to guarantee the validity of the questionnaire, all respondents are middle or senior managers. All questionnaires were distributed through three ways. First, we distributed 150 questionnaires through a professional data company in China named Survey Star. Second, relying on the personal relationships between the research group members and relevant high-tech manufacturing SMEs, we distributed 133 questionnaires through emails. Third, 175 paper version questionnaires were distributed to MBA and EMBA students working in the SMEs that meet the requirements. The process of questionnaire distribution lasted for two months, and 458 questionnaires were sent out. Finally, we received 213 useable questionnaires, for an effective response rate of $46.5 \%$. The information of the sample firms involved in this study is shown in Table 1.

Table 1. Profiles of the sample firms.

\begin{tabular}{ccc}
\hline Sample Characteristics & Frequency & $\%$ \\
\hline Firm age (number of years) & 41 & \\
$<5$ & 94 & 49.25 \\
$5-10$ & 78 & 36.62 \\
$>10$ & & \\
\hline Firm size (number of employees) & 22 & 10.33 \\
<50 300 & 97 & 45.54 \\
$300-1000$ & 94 & 44.13 \\
\hline$<3$ & & \\
$3-20$ & 33 & 15.49 \\
$20-400$ & 81 & 38.03 \\
Industry & 99 & 46.48 \\
\hline Annual sales (million RMB) & & \\
Electronic communication & 89 & 41.78 \\
Machinery and instrumentation & 54 & 25.35 \\
Bio-pharmaceutical & 48 & 22.54 \\
Other industries & 22 & 10.33 \\
\hline Ownership & & \\
State-owned & 22 & 10.33 \\
Private-owned & 64 & 59.62 \\
Foreign-owned & 30.05 \\
\hline
\end{tabular}

\subsection{Variable Measurement}

This study consists of five main constructs including formal external collaboration, informal external collaboration, managers' entrepreneurial orientation, organizational legitimacy, and innovation performance. All these constructs were measured using five-point Linkert scales (1-5), and the measurement items were adapted from the existing literature.

Dependent variable: Rather than using secondary data, this study followed the research of Bell [76] and Ahn [77], and used five items to measure the innovation performance of SMEs. Items were 
speed of new product development, speed of new technologies adoption, success rate of new product development, profitability of new products, and innovativeness of new products. Respondents were required to indicate the relative innovation performance on a five-point Linkert scale $(1=$ completely disagree; $5=$ completely agree), when compared with the industry average.

Independent variable: Based on the studies of Santoro et al. [16] and Mina et al. [47], and information obtained from in-depth interviews, we used seven items to measure formal external collaboration. On a five-point scale (anchored on $1=$ never, and $5=$ very often), respondents were asked to indicate the extent to which the SMEs collaborate with their main partners through contractual methods and participate in other formal external collaboration activities such as venture investment, patent purchase, and technology licensing. Similarly, we measured informal external collaboration on a five-point scale (anchored on $1=$ never, and $5=$ very often) by asking respondents to indicate the extent to which the SMEs make contact with their main partners via informal methods and engage in other informal external collaboration activities such as conferences and meetings. Like formal external collaboration, the measurement items for informal external collaboration were also based on previous external collaboration research $[16,47]$ and the interviews with SMEs managers.

Moderating variables: A six-items scale adapted from Covin and Lumpkin [61] and Wang [78] was used to evaluate the level of managers' entrepreneurial orientation. Specifically, the six-items scale measured three dimensions: Innovativeness, risk-taking, and proactiveness. In addition, we adapted measures of organizational legitimacy from Elsbach [79] and Certo and Hodge [80]. Using six measurement items, the organizational legitimacy scale captures the extent to which a firm is approved by stakeholders, including the general public, suppliers, customers, competitors, governments, and employees. All items were validated on a five-point scale anchored by $1=$ "completely disagree" and $5=$ "completely agree".

Controls: Considering the study's context and outcome variable (innovation performance), we included two firm-level variables and one industry-level variable in this study, including firm size, firm age, and competitive intensity. Firm size was measured by the natural logarithm of the number of employees. Firm age was measured by the number of years the firm has been in operation. Moreover, we measured competitive intensity with four items adopted from Jansen et al. [81] and anchored it on a five-point scale. Details of the measurement items are available in Table 2.

\subsection{Construct Validity and Reliability}

Following the research of Anderson and Gerbing [82], we performed confirmatory factor analysis with structural equation modeling to assess construct validity and evaluate the overall measurement. The measurement model fitted the data satisfactorily $\left(\chi^{2} / \mathrm{df}=1.271\right.$, goodness-of-fit index $=0.900$, comparative fit index $=0.965$, incremental fit index $=0.965$, root mean square error of approximation $=0.036)$. All factor loadings were highly significant $(p<0.001)$, ranging from 0.749 to 0.881 , indicating the unidimensionality of the measures. The Cronbach's $\alpha$ values were all above the threshold of 0.70 , ranging from 0.838 to 0.921 . The composite reliability (CR) for each construct surpassed the recommended 0.70 cutoff, ranging from 0.883 to 0.929 . The average variance extracted (AVE) for each construct was above the 0.50 threshold, ranging from 0.600 to 0.685 . Thus, all measures had adequate convergent validity and reliability. Then, we evaluated the discriminant validity of the measures using the AVE method. Table 3 indicates that the square roots of AVE of all constructs (diagonal elements in bold) were much higher than the corresponding inter-construct correlations, providing strong support for discriminant validity. 
Table 2. Measurement items and validity assessment.

\begin{tabular}{|c|c|}
\hline Measurement Items & Factor Loadings \\
\hline \multicolumn{2}{|l|}{ Innovation performance (IP): $\mathrm{CR}=0.883 ; \mathrm{AVE}=0.600 ;$ Cronbach's $\alpha=0.858$} \\
\hline The speed of our firm's new product development is fast & 0.786 \\
\hline The speed of our firm's new technologies adoption is fast & 0.770 \\
\hline The success rate of our firm's new product development is high & 0.781 \\
\hline The profitability of our firm's new products is high & 0.787 \\
\hline Our firm's new products are highly innovative & 0.749 \\
\hline \multicolumn{2}{|l|}{ Formal external collaboration (FEC): $\mathrm{CR}=0.929 ; \mathrm{AVE}=0.652 ;$ Cronbach's $\alpha=0.919$} \\
\hline Collaborating with suppliers based on formal contracts or agreements & 0.833 \\
\hline Collaborating with customers based on formal contracts or agreements & 0.807 \\
\hline Collaborating with competitors based on formal contracts or agreements & 0.811 \\
\hline Collaborating with universities and research institutes based on formal contracts or agreements & 0.782 \\
\hline Venture investments, mergers, and acquisitions & 0.801 \\
\hline Patent purchase & 0.798 \\
\hline Licensing in externally developed technologies & 0.818 \\
\hline \multicolumn{2}{|l|}{ Informal external collaboration (IEC): $\mathrm{CR}=0.929 ; \mathrm{AVE}=0.650 ;$ Cronbach's $\alpha=0.921$} \\
\hline Communicating and contacting with suppliers via informal methods & 0.831 \\
\hline Communicating and contacting with customers via informal methods & 0.835 \\
\hline Communicating and contacting with competitors via informal methods & 0.800 \\
\hline Communicating and contacting with universities and research institutes via informal methods & 0.795 \\
\hline Sharing facilities with other organizations or researchers & 0.798 \\
\hline Participating in related meetings, conferences, and trade fairs & 0.797 \\
\hline Participating in related associations, clubs, and leisure activities & 0.786 \\
\hline \multicolumn{2}{|l|}{ Managers' entrepreneurial orientation (MEO): $\mathrm{CR}=0.914 ; \mathrm{AVE}=0.640 ;$ Cronbach's $\alpha=0.889$} \\
\hline Managers of our firm put strong emphasis on R\&D, technological leadership, and innovations & 0.823 \\
\hline Managers of our firm are willing to try new ways of doing things and seek novel solutions & 0.804 \\
\hline Managers of our firm have a strong proclivity for high-risk projects & 0.804 \\
\hline Managers of our firm believe that bold, wide-ranging acts are important to firm's success & 0.770 \\
\hline Managers of our firm are willing to adopt a very competitive, "undo-the-competitors" posture & 0.829 \\
\hline Managers of our firm often initiate actions to which our competitors have to respond & 0.766 \\
\hline \multicolumn{2}{|l|}{ Organizational legitimacy (OL): $\mathrm{CR}=0.929 ; \mathrm{AVE}=0.685 ;$ Cronbach's $\alpha=0.905$} \\
\hline The general public approves of our firm's operating procedures & 0.778 \\
\hline Suppliers want to do business with our firm & 0.802 \\
\hline Customers highly value the products produced by our firm & 0.834 \\
\hline Competitors view our firm with respect & 0.796 \\
\hline Governments highly approve of our firm & 0.869 \\
\hline Employees are proud to tell others they work at our firm & 0.881 \\
\hline \multicolumn{2}{|l|}{ Competitive intensity $(\mathrm{CI}): \mathrm{CR}=0.885 ; \mathrm{AVE}=0.657 ;$ Cronbach's $\alpha=0.838$} \\
\hline Competition in our local market is cut-throat & 0.821 \\
\hline Price competition in our industry is very frequent & 0.803 \\
\hline We hear of new competitive moves in terms of new product development every day & 0.804 \\
\hline Anything that my company can offer, another company can match readily & 0.814 \\
\hline
\end{tabular}

Notes: $\mathrm{CR}=$ composite reliability; AVE = average variance extracted. 
Table 3. Descriptive statistics and correlation matrix.

\begin{tabular}{ccccccccc}
\hline Variable & $\mathbf{1}$ & $\mathbf{2}$ & $\mathbf{3}$ & $\mathbf{4}$ & $\mathbf{5}$ & $\mathbf{6}$ & $\mathbf{7}$ & $\mathbf{8}$ \\
\hline Size & N/A & & & & & & & \\
Age & $0.138^{*}$ & N/A & & & & & & \\
CI & 0.048 & 0.105 & $\mathbf{0 . 8 1 1}$ & & & & & \\
FEC & 0.046 & 0.069 & 0.122 & $\mathbf{0 . 8 0 8}$ & & & & \\
IEC & 0.036 & 0.041 & 0.065 & $0.275^{* *}$ & $\mathbf{0 . 8 0 6}$ & & & \\
MEO & 0.100 & 0.108 & $0.179 * *$ & 0.031 & -0.108 & $\mathbf{0 . 8 0 0}$ & & \\
OL & -0.078 & 0.058 & -0.089 & 0.131 & -0.026 & -0.032 & $\mathbf{0 . 8 2 8}$ & \\
IP & 0.084 & 0.109 & -0.014 & $0.274 * *$ & $0.338^{* *}$ & $0.011^{*}$ & $0.136^{*}$ & $\mathbf{0 . 7 7 5}$ \\
Mean & 5.358 & 9.540 & 3.783 & 3.013 & 3.300 & 2.632 & 2.929 & 3.592 \\
SD & 0.951 & 5.461 & 0.818 & 0.950 & 0.909 & 0.683 & 0.802 & 0.764 \\
\hline
\end{tabular}

Notes: $\mathrm{N}=213 ;{ }^{*} p<0.05 ;{ }^{* *} p<0.01$; N/A: not suitable for analysis; Diagonal elements (in bold) are the square roots of the AVE values.

\subsection{Common Method Bias}

Both the dependent and independent variables were measured by the same respondents, so common method bias may exist in this study. Therefore, we performed Harman's one-factor test through exploratory factor analysis to assess whether there was a common method bias [83]. The results showed that the first factor only explained $27.34 \%$ of the variance, and therefore the common method bias was not a major concern in this study, permitting us to test our hypotheses.

\section{Results}

Table 3 displays the descriptive statistics, including means, standard deviations (SD), and correlations of the relevant variables in our study. To test whether hierarchical regression analysis would be suitable for our study, we checked for serial correlation, heteroscedasticity, and multicollinearity. The results demonstrate the appropriateness of hierarchical regression analysis in testing the hypotheses. According to the above test results and following the research of Zhu et al. [84], hierarchical regression analysis was used for testing the proposed hypotheses, and the results are shown in Table 4. In addition, the variance inflation factor (VIF) of all variables were below 2, indicating that multicollinearity is not a problem in our study.

Table 4. Results of regression analysis.

\begin{tabular}{|c|c|c|c|c|c|c|}
\hline Variables & Model 1 & Model 2 & Model 3 & Model 4 & Model 5 & Model 6 \\
\hline Size & 0.071 & 0.064 & 0.051 & 0.056 & 0.067 & 0.057 \\
\hline Age & 0.102 & 0.073 & 0.082 & 0.085 & 0.093 & 0.066 \\
\hline $\mathrm{CI}$ & -0.028 & -0.059 & -0.083 & -0.063 & -0.061 & -0.050 \\
\hline FCN & & $0.179 * *$ & $0.191 * *$ & $0.196^{* *}$ & 0.143 * & $0.163 *$ \\
\hline $\mathrm{ICN}$ & & $0.293^{* * * *}$ & $0.286^{* * *}$ & $0.290 * * *$ & $0.275^{* * *}$ & $0.270 * * *$ \\
\hline MEO & & 0.026 & 0.017 & 0.034 & & \\
\hline OL & & 0.116 & & & 0.105 & 0.119 \\
\hline $\mathrm{FCN} \times \mathrm{MEO}$ & & & 0.065 & & & \\
\hline $\mathrm{ICN} \times \mathrm{MEO}$ & & & & 0.138 * & & \\
\hline $\mathrm{FCN} \times \mathrm{OL}$ & & & & & $0.215^{* *}$ & \\
\hline $\mathrm{ICN} \times \mathrm{OL}$ & & & & & & $0.193 * *$ \\
\hline $\mathrm{R}^{2}$ & 0.017 & 0.177 & 0.178 & 0.183 & 0.221 & 0.213 \\
\hline Adj. $R^{2}$ & 0.003 & 0.149 & 0.150 & 0.155 & 0.194 & 0.186 \\
\hline $\mathrm{F}$ & 1.235 & $6.317^{* * *}$ & $5.933^{* * *}$ & $6.573^{* * *}$ & $8.302^{* * *}$ & $7.927^{* * *}$ \\
\hline
\end{tabular}

We followed a hierarchical procedure and estimated different models where the dependent variable is innovation performance (Table 4). First, we analyzed the effect of three control variables in Model 1. Second, in Model 2, we included the two independent variables and two moderators. 
In the third step, in order to test the moderating effects, the interactions of independent variables and moderators were included to test their effects on the dependent variables in Model 3 to Model 6 , respectively. Specifically, Model 3 and 4 included the interaction terms for managers' entrepreneurial orientation and formal and informal external collaboration, respectively. The moderating effects of organizational legitimacy on formal and informal external collaboration were tested in Model 5 and 6 . To minimize potential multicollinearity, we mean-centered all interaction variables [85].

As Model 2 shows, both formal and informal external collaboration have positive and significant impacts on the innovation performance of SMEs (formal external collaboration: $\beta=0.179, p<0.01$; informal external collaboration: $\beta=0.293, p<0.001$ ), and the path coefficients of informal external collaboration is higher, indicating that both types of external collaboration contribute to innovation performance of SMEs, and informal external collaboration is more beneficial for the improvements of SMEs' innovation performance than formal external collaboration. Thus, $\mathrm{H} 1$ and $\mathrm{H} 2$ are supported.

As Model 3 indicates, the moderating effect of managers' entrepreneurial orientation on the formal external collaboration-innovation performance relationship is non-significant $(\beta=0.065, p>0.05)$, indicating that managers' entrepreneurial orientation does not significantly impact the relationship between formal external collaboration and innovation performance of SMEs, and H3a is not supported. Moreover, as Model 4 shows, the moderating effect of managers' entrepreneurial orientation on the informal external collaboration-innovation performance relationship is positive and significant $(\beta=0.138, p<0.05)$, indicating that managers' entrepreneurial orientation strengthens the positive effect of informal external collaboration on the innovation performance of SMEs, and H3b is supported. According to Aiken et al. [85], we plotted the relationship between informal external collaboration and innovation performance of SMEs for the low and high level of managers' entrepreneurial orientation in Figure 2. The plot shows that the slope of the line is steeper for high managers' entrepreneurial orientation, in support of $\mathrm{H} 3 \mathrm{~b}$.

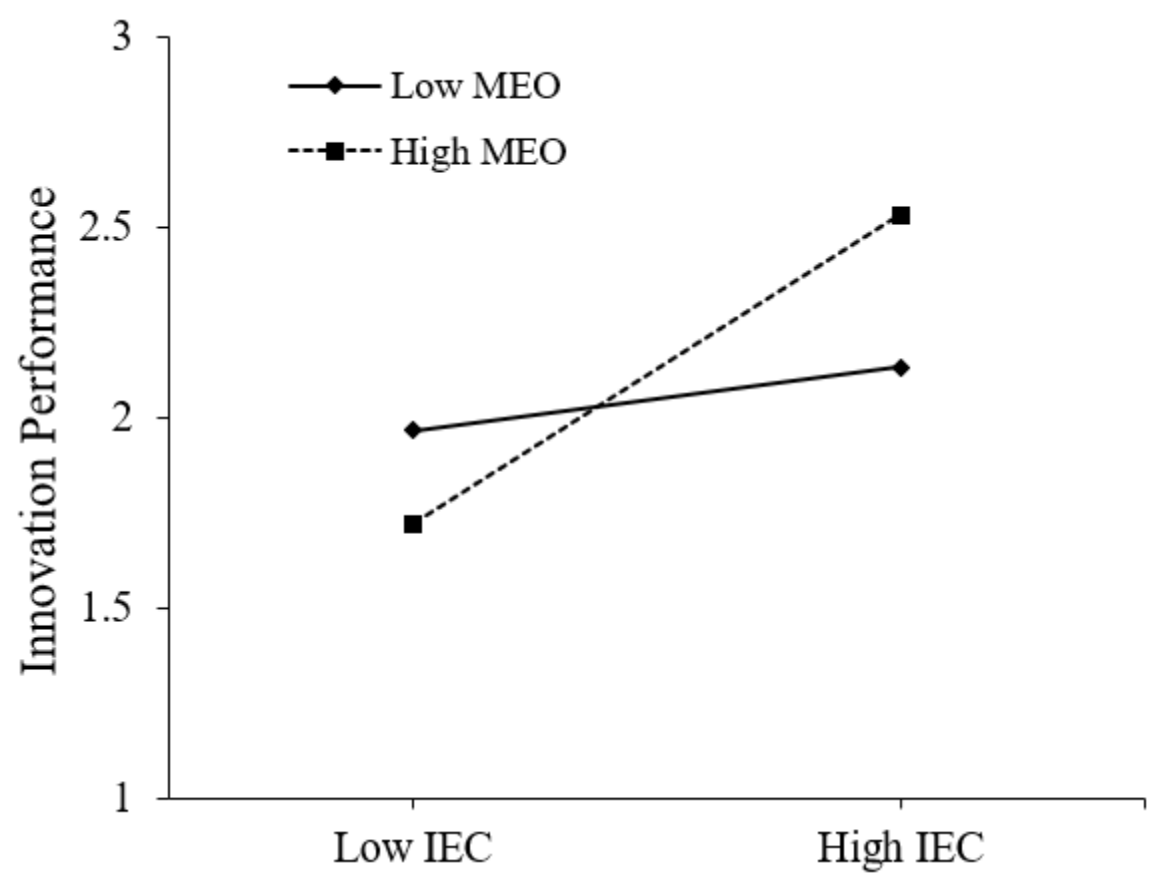

Figure 2. The moderating effect of managers' entrepreneurial orientation (MEO) on informal external collaboration (IEC)-innovation performance relationship.

In addition, as Model 5 shows, the coefficient of the interaction of organizational legitimacy with formal external collaboration is positive and significant $(\beta=0.215, p<0.01)$, indicating that the positive impact of formal external collaboration on the innovation performance of SMEs strengthens with organizational legitimacy. Moreover, as Model 6 indicates, the coefficient of the interaction of 
organizational legitimacy with the informal external collaboration is also positive and significant $(\beta=0.193, p<0.01)$, indicating the positive impact of informal external collaboration on innovation performance of SMEs is strengthened. Therefore, $\mathrm{H} 4 \mathrm{a}$ and $\mathrm{H} 4 \mathrm{~b}$ are supported. We also plotted the effects of low and high levels of organizational legitimacy on the relationships between two types of external collaboration and innovation performance of SMEs [85]. The plots, presented in Figures 3 and 4, suggest that the positive impacts of formal an informal external collaboration on innovation performance of SMEs is higher when organizational legitimacy is high than when it is low. Overall, $\mathrm{H} 4 \mathrm{a}$ and $\mathrm{H} 4 \mathrm{~b}$ are further supported by these plots.

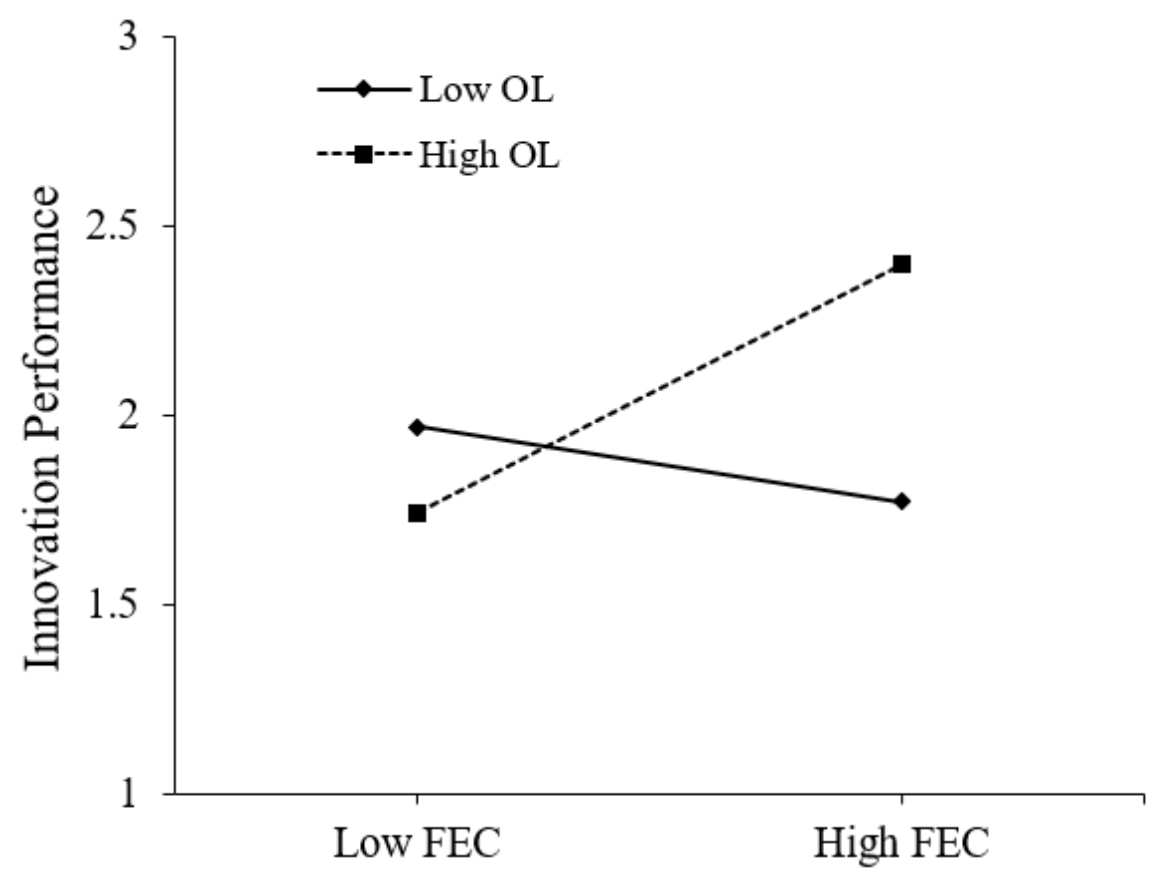

Figure 3. The moderating effect of organizational legitimacy (OL) on formal external collaboration (FEC)-innovation performance relationship.

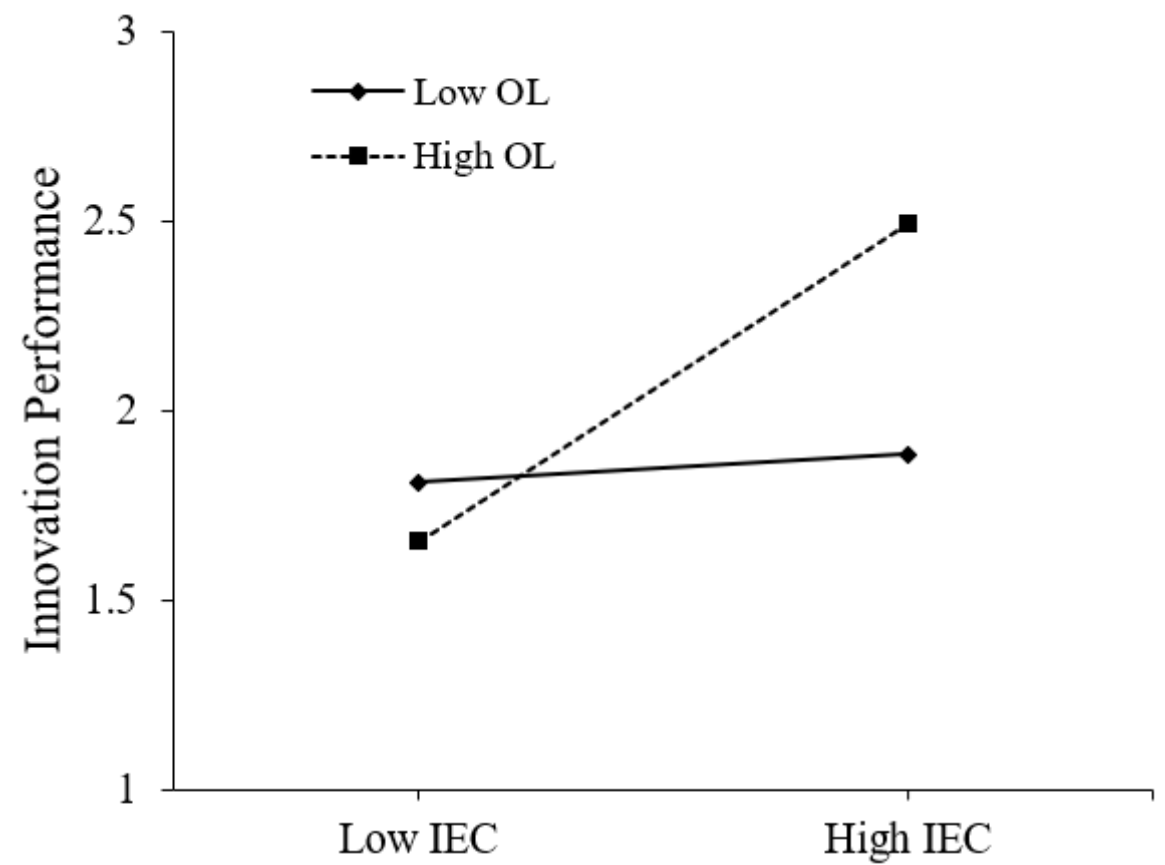

Figure 4. The moderating effect of organizational legitimacy (OL) on informal external collaboration (IEC)-innovation performance relationship. 


\section{Discussion}

\subsection{Main Findings}

The aim of this study is to explore the impacts of formal and informal external collaboration on SMEs' innovation performance and investigate the moderating effects of managers' entrepreneurial orientation and organizational legitimacy on the above relationships.

This study finds that both formal and informal external collaboration have positive effects on SMEs' innovation performance, and informal external collaboration offers greater benefits than formal external collaboration. Innovation is complex, costly, and risky, and a single SME does not have enough resources and capabilities to achieve successful innovation. The results from the quantitative study suggested that, as important forms of external collaboration, both formal and informal external collaboration are effective ways for SMEs to overcome these problems and improve innovation performance through acquiring crucial external knowledge and resources, and decreasing the costs and risks of innovation. This conclusion is in line with the basic viewpoint of open innovation theory, and it is similar to those of Laursen and Salter, who found that open innovation has a positive impact on firms' innovation performance [86]. Moreover, compared with formal external collaboration, informal collaboration is more effective in enhancing SMEs' innovation performance. This can be explained as follows. Compared with formal external collaboration, the cost of informal collaboration is lower, and in the process of external knowledge acquirement, informal external collaboration is quicker and more flexible. In addition, due to the low credit and high uncertainty, it is difficult for SMEs to build collaborative relationships with large firms and obtain useful knowledge from them. However, through informal communications with large firms, SMEs tend to acquire useful knowledge which large firms disclosed unintentionally. This conclusion is similar to those of Santoro et al. [16] and Gulati [87], who stated that firms prefer informal modes for collaboration, and those of Van de Vrande et al. [2], who noted that SMEs tend to choose informal ties to avoid too much investment.

This study also reveals that managers' entrepreneurial orientation contributes positively to the effect of informal external collaboration on innovation performance of SMEs. This means that when the managers are more active to engage in innovative, risk-taking, and proactive behaviors, the firms they serve would benefit more from informal external collaboration. This result is similar to those of previous research that indicated that CEOs' characteristics, such as entrepreneurial orientation, plays an important role in enhancing open innovation effectiveness [23,88]. However, the moderating effect of managers' entrepreneurial orientation on formal external collaboration-SMEs' innovation performance relationship is not verified. The possible explanation is that although high managers' entrepreneurial orientation can stimulate the SMEs to collaborate with external partners more actively and help them obtain large amount of useful external resources through formal external collaboration, these external heterogeneous resources may not be absorbed and transformed into innovation outcome. Therefore, high managers' entrepreneurial orientation alone is not enough to moderate the relationship between formal external collaboration and SMEs' innovation performance.

The last important finding of this study regards the moderating effects of organizational legitimacy. In detail, organizational legitimacy has positive moderating effects on the relationships between formal and informal external collaboration and innovation performance of SMEs. The result demonstrates that the benefits associated with formal and informal external collaboration are not homogeneous for all SMEs, but depend on and are intertwined with firms' organizational legitimacy. Organizational legitimacy is important for SMEs' open innovation, and it can strengthen the benefits of formal and informal external collaboration on SMEs' innovation performance by reducing costs of collaboration, gaining trust from partners, acquiring more useful external knowledge, and enhancing employees' loyalty. This result is similar to those of Tsinopoulos et al. [27], who posited that when a firm's motivation to achieve legitimacy increases, the effectiveness of the external co-operation with external organizations is also likely to increase, and those of Martinez-Costa et al. [89], who found that meeting regulatory requirements, legislation, and various standards requires a systematic engagement with 
external partners, and such engagement can amplify the influence of collaborative networks on firms' performance.

\subsection{Theoretical Implications}

This study contributes to the literature in several ways. First, based on the perspective of formal and informal, this study extends the research on external collaboration-innovation performance relationship by differentiating two types of external collaboration, formal external collaboration and informal external collaboration, and exploring their different effects on the innovation performance of SMEs. Existing studies have mainly paid attention to the breadth and depth of external collaboration [8,9], intraand inter-regional external collaboration [10,11], and academic and industrial collaboration [12,13]. Most of them have ignored the fact that formal and informal collaboration are very common in SMEs' open innovation activities, and neglected the necessity to explore their different effects on SMEs' innovation performance. Therefore, this study provides a new perspective for the theoretical study on open innovation and external collaboration, and it expands the theoretical research on the antecedent variables of firms' innovation performance.

Second, this study further extends the research on external collaboration-innovation performance relationship by integrating leadership trait theory and institutional theory with open innovation theory to account for the moderating effects of managers' entrepreneurial orientation and organizational legitimacy. Existing studies have mainly focused on the contingency role of external factors such as technological uncertainty [35] and government support [36], and internal competency factors such as absorptive capacity [16]. However, the internal mechanism in the relationship between formal and informal external collaboration and innovation performance remains unclear. Previous studies have neglected the contingency role of managers' entrepreneurial orientation and organizational legitimacy in moderating the relationships between formal/informal external collaboration and innovation performance. Through integrating managers' entrepreneurial orientation and organizational legitimacy into the research framework of formal/informal external collaboration and innovation performance of SMEs, this study further identifies the boundary conditions between formal/informal external collaboration and SMEs' innovation performance. Besides, this study is helpful to explain why some SMEs can benefit from formal and informal external collaboration activities while others cannot.

Third, this study focuses on SMEs' external collaboration activities, and explores the interactive mechanisms between formal/informal external collaboration, managers' entrepreneurial orientation, organizational legitimacy, and SMEs' innovation performance. The research findings highlight that SMEs' linkages with external organizations through formal and informal collaboration both have positive effects on their innovation performance. Besides, our research shows the importance of managers' entrepreneurial orientation and organizational legitimacy on SMEs' external collaboration and the contingency moderating effects of managers' entrepreneurial orientation and organizational legitimacy on the relationships between SMEs' formal/informal external collaboration and innovation performance. Therefore, this study fills the open innovation research gap proposed by Van de Vrande et al. that "little is known about open innovation in the context of SMEs" [2]. Besides, as few of the previous studies have examined SMEs' open innovation empirically, this study responds to the latest calls in the field of open innovation that research should use large-scale data to explore SMEs' open innovation [90].

\subsection{Practical Implications}

Our findings have several important practical implications. First, our results suggest that both formal and informal external collaboration are effective ways for SMEs to acquire external resources, reduce costs and risks of innovation, and improve innovation performance. Therefore, managers of SMEs should attach great importance to the positive role of formal and informal external collaboration in accelerating the SMEs' innovation performance. As the employed items indicate, formal external collaboration involves collaborating with suppliers, customers, competitors, and universities and 
research institutes based on formal contract or agreements, implementing venture investments, mergers, and acquisitions, purchasing patents, and licensing in externally developed technologies. Informal external collaboration involves scanning ideas and knowledge from external organizations, participating in meetings, conferences, and related associations, and sharing facilities with other organizations or researchers. To improve innovation performance, managers of SMEs should consider these ways in their policies and managerial processes. In addition, the results indicate that compared with formal external collaboration, informal external collaboration leads to a higher innovation performance. This suggests that managers of SMEs need to pay more attention to informal external collaboration, and they should spend more time and effort in tapping into the external resources and knowledge through informal ties.

Second, the results of this study indicate that managers' entrepreneurial orientation moderates the positive relationship between informal external collaboration and SMEs' innovation performance. Our findings remind managers of SMEs that in the process of their firms' informal external collaboration, their behavior should follow the spirit of innovativeness, risk tolerance, and proactiveness. At the same time, managers of SMEs should share the entrepreneurial spirit with all the employees in their firms through some management measures. For example, in the practice of SMEs management, managers of SMEs can reward employees for their innovative and risk-taking behavior, and cultivate the culture of trial and error within the SMEs they serve. Besides, our results also indicate that in the process of manager selection, the boards of directors of SMEs should regard candidates' entrepreneurial orientation as an important factor. In addition, governments should vigorously propagandize the importance of managers' entrepreneurial orientation, and strengthen the guidance to SMEs' managers.

Third, this study emphasizes the importance of organizational legitimacy in conditioning the formal and informal external collaboration and SMEs' innovation performance relationships. It suggests that organizational legitimacy is critical for strengthening the benefits of formal and informal external collaboration on innovation performance of SMEs. Therefore, managers of SMEs should struggle to establish, maintain, and enhance their organizational legitimacy, and try hard to obtain more approval and support from their stakeholders. For example, in order to gain approval from the government and improve organizational legitimacy, SMEs should obey various rules, laws, and regulations set by the government, and try hard to achieve the goals set by the government for SMEs such as energy conservation and emission reduction. Besides, in order to gain approval from market entities such as suppliers, customers, and competitors, SMEs should try hard to maintain good relationships with them through frequent contact and communication, actively participate in activities organized by industry associations, obey market standards, persist in honest operation, improve the quality of their products, and engage in more corporate social responsibility activities.

\subsection{Limitations and Future Directions}

This study has several limitations which might suggest new directions for future research. First, the data used in this study was only collected from high-tech manufacturing SMEs in some specific Chinese areas; however, this may restrain the generalizability of our findings. In the future, additional research can incorporate other industries in the sampling process and collect data from other regions in China to validate the findings and examine the generalizability of our findings.

Second, this study is designed in a cross-sectional nature, and cannot reflect the dynamic evolution of formal and informal external collaboration. Future research should conduct longitudinal studies to analyze how the relationships between formal and informal external collaboration and SMEs' innovation performance dynamically change over time.

Third, this study only regarded one micro level factor named managers' entrepreneurial orientation as a contingent factor and explored its moderating effect on external collaboration and SMEs' innovation performance relationship. However, in the field of open innovation, research on the micro level contingent factors remains insufficient. Future studies can pay more attention to the "human side" 
of open innovation, and explore how individual characteristics such as employees' work satisfaction affect the effectiveness of SMEs' external collaboration.

Author Contributions: Conceptualization, C.L. and B.Y.; data curation, C.L.; formal analysis, C.L.; funding acquisition, B.Y.; investigation, C.L.; methodology, C.L.; project administration, B.Y.; resources, B.Y.; software, C.L.; supervision, B.Y.; validation, C.L. and B.Y.; visualization, C.L.; writing-original draft preparation, C.L.; writing-review and editing, B.Y. All authors have read and agreed to the published version of the manuscript.

Funding: This research was funded by the National Social Science Foundation of China (grant number 16AZD006).

Conflicts of Interest: The authors declare no conflict of interest.

\section{References}

1. Bogers, M.; Chesbrough, H.; Moedas, C. Open innovation: Research, practices, and policies. Calif. Manag. Rev. 2018, 60, 5-16. [CrossRef]

2. Van de Vrande, V.; De Jong, J.P.; Vanhaverbeke, W.; De Rochemont, M. Open innovation in SMEs: Trends, motives and management challenges. Technovation 2009, 29, 423-437. [CrossRef]

3. Spithoven, A.; Vanhaverbeke, W.; Roijakkers, N. Open innovation practices in SMEs and large enterprises. Small Bus. Econ. 2013, 41, 537-562. [CrossRef]

4. Kafouros, M.; Love, J.H.; Ganotakis, P.; Konara, P. Experience in R\&D collaborations, innovative performance and the moderating effect of different dimensions of absorptive capacity. Technol. Forecast. Soc. Chang. 2020, 150, 119757.

5. Chapman, G.; Lucena, A.; Afcha, S. R\&D subsidies \& external collaborative breadth: Differential gains and the role of collaboration experience. Res. Policy 2018, 47, 623-636.

6. Fernández-Olmos, M.; Ramírez-Alesón, M. How internal and external factors influence the dynamics of SME technology collaboration networks over time. Technovation 2017, 64, 16-27. [CrossRef]

7. Bianchi, M.; Croce, A.; Dell'Era, C.; Di Benedetto, C.A.; Frattini, F. Organizing for inbound open innovation: How external consultants and a dedicated R\&D unit influence product innovation performance. J. Prod. Innov. Manag. 2016, 33, 492-510.

8. Shi, X.; Zhang, Q.; Zheng, Z. The double-edged sword of external search in collaboration networks: Embeddedness in knowledge networks as moderators. J. Knowl. Manag. 2019, 23. [CrossRef]

9. Kobarg, S.; Stumpf-Wollersheim, J.; Welpe, I.M. More is not always better: Effects of collaboration breadth and depth on radical and incremental innovation performance at the project level. Res. Policy 2019, 48, 1-10. [CrossRef]

10. De Noni, I.; Ganzaroli, A.; Orsi, L. The impact of intra-and inter-regional knowledge collaboration and technological variety on the knowledge productivity of European regions. Technol. Forecast. Soc. Chang. 2017, 117, 108-118. [CrossRef]

11. Broekel, T. Collaboration intensity and regional innovation efficiency in Germany-A conditional efficiency approach. Ind. Innov. 2012, 19, 155-179. [CrossRef]

12. Mei, L.; Zhang, T.; Chen, J. Exploring the effects of inter-firm linkages on SMEs' open innovation from an ecosystem perspective: An empirical study of Chinese manufacturing SMEs. Technol. Forecast. Soc. Chang. 2019, 144, 118-128. [CrossRef]

13. D'Angelo, A.; Baroncelli, A. An investigation over inbound open innovation in SMEs: Insights from an Italian manufacturing sample. Technol. Anal. Strateg. Manag. 2020, 32, 542-560. [CrossRef]

14. Salavisa, I.; Sousa, C.; Fontes, M. Topologies of innovation networks in knowledge-intensive sectors: Sectoral differences in the access to knowledge and complementary assets through formal and informal ties. Technovation 2012, 32, 380-399. [CrossRef]

15. Gilsing, V.; Nooteboom, B.; Vanhaverbeke, W.; Duysters, G.; Van den Oord, A. Network embeddedness and the exploration of novel technologies: Technological distance, betweenness centrality and density. Res. Policy 2008, 37, 1717-1731. [CrossRef]

16. Santoro, G.; Bresciani, S.; Papa, A. Collaborative modes with cultural and creative industries and innovation performance: The moderating role of heterogeneous sources of knowledge and absorptive capacity. Technovation 2020, 92, 102040. [CrossRef] 
17. Bianchi, M.; Campodall'Orto, S.; Frattini, F.; Vercesi, P. Enabling open innovation in small-and medium-sized enterprises: How to find alternative applications for your technologies. $R$ D Manag. 2010, 40, 414-431. [CrossRef]

18. Chesbrough, H.W.; Appleyard, M.M. Open innovation and strategy. Calif. Manag. Rev. 2007, 50, 57-76. [CrossRef]

19. Gassmann, O.; Enkel, E.; Chesbrough, H. The future of open innovation. R D Manag. 2010, 40, $213-221$. [CrossRef]

20. Chatterjee, A.; Hambrick, D.C. Executive personality, capability cues, and risk taking: How narcissistic CEOs react to their successes and stumbles. Adm. Sci. Q. 2011, 56, 202-237. [CrossRef]

21. Cho, S.Y.; Kim, S.K. Horizon problem and firm innovation: The influence of CEO career horizon, exploitation and exploration on breakthrough innovations. Res. Policy 2017, 46, 1801-1809. [CrossRef]

22. Finkelstein, S.; Hambrick, D.C. Top-management-team tenure and organizational outcomes: The moderating role of managerial discretion. Adm. Sci. Q. 1990, 35, 484-503. [CrossRef]

23. Santoro, G.; Quaglia, R.; Pellicelli, A.C.; De Bernardi, P. The interplay among entrepreneur, employees, and firm level factors in explaining SMEs openness: A qualitative micro-foundational approach. Technol. Forecast. Soc. Chang. 2020, 151, 119820. [CrossRef]

24. Davis, J.L.; Bell, R.G.; Payne, G.T.; Kreiser, P.M. Entrepreneurial orientation and firm performance: The moderating role of managerial power. Am. J. Bus. 2010, 25, 232-248. [CrossRef]

25. Zimmerman, M.A.; Zeitz, G.J. Beyond survival: Achieving new venture growth by building legitimacy. Acad. Manag. Rev. 2002, 27, 414-431. [CrossRef]

26. Delmar, F.; Shane, S. Legitimating first: Organizing activities and the survival of new ventures. J. Bus. Ventur. 2004, 19, 385-410. [CrossRef]

27. Tsinopoulos, C.; Sousa, C.M.; Yan, J. Process innovation: Open innovation and the moderating role of the motivation to achieve legitimacy. J. Prod. Innov. Manag. 2018, 35, 27-48. [CrossRef]

28. Robson, P.J.; Bennett, R.J. SME growth: The relationship with business advice and external collaboration. Small Bus. Econ. 2000, 15, 193-208. [CrossRef]

29. Radicic, D.; Pinto, J. Collaboration with External Organizations and Technological Innovations: Evidence from Spanish Manufacturing Firms. Sustainability 2019, 11, 2479. [CrossRef]

30. Ahuja, G. Collaboration networks, structural holes, and innovation: A longitudinal study. Adm. Sci. Q. 2000, 45, 425-455. [CrossRef]

31. Zeng, S.X.; Xie, X.M.; Tam, C.M. Relationship between cooperation networks and innovation performance of SMEs. Technovation 2010, 30, 181-194. [CrossRef]

32. Parida, V.; Westerberg, M.; Frishammar, J. Inbound open innovation activities in high-tech SMEs: The impact on innovation performance. J. Small Bus. Manag. 2012, 50, 283-309. [CrossRef]

33. Findik, D.; Beyhan, B. The impact of external collaborations on firm innovation performance: Evidence from Turkey. Soc. Behav. Sci. 2015, 195, 1425-1434. [CrossRef]

34. Kang, K.H.; Kang, J. How do firms source external knowledge for innovation? Analysing effects of different knowledge sourcing methods. Int. J. Innov. Manag. 2009, 13, 1-17. [CrossRef]

35. Jiao, H.; Yang, J.; Zhou, J. Commercial partnerships and collaborative innovation in China: The moderating effect of technological uncertainty and dynamic capabilities. J. Knowl. Manag. 2019, 23, 112-143. [CrossRef]

36. Lu, C.; Yu, B.; Zhang, J.; Xu, D. Effects of open innovation strategies on innovation performance of SMEs: Evidence from China. Chin. Manag. Stud. 2020. [CrossRef]

37. Hoang, H.A.; Rothaermel, F.T. Leveraging internal and external experience: Exploration, exploitation, and R\&D project performance. Strateg. Manag. J. 2010, 31, 734-758.

38. Grindley, P.C.; Teece, D.J. Managing intellectual capital: Licensing and cross-licensing in semiconductors and electronics. Calif. Manag. Rev. 1997, 39, 8-41. [CrossRef]

39. Singh, H.; Kryscynski, D.; Li, X.; Gopal, R. Pipes, pools, and filters: How collaboration networks affect innovative performance. Strateg. Manag. J. 2016, 37, 1649-1666. [CrossRef]

40. Caputo, M.; Lamberti, E.; Cammarano, A.; Michelino, F. Exploring the impact of open innovation on firm performances. Manag. Decis. 2016, 54. [CrossRef]

41. Flor, M.L.; Cooper, S.Y.; Oltra, M.J. External knowledge search, absorptive capacity and radical innovation in high-technology firms. Eur. Manag. J. 2018, 36, 183-194. [CrossRef] 
42. Lee, S.; Park, G.; Yoon, B.; Park, J. Open innovation in SMEs-An intermediated network model. Res. Policy 2010, 39, 290-300. [CrossRef]

43. Leiponen, A.; Helfat, C.E. Innovation objectives, knowledge sources, and the benefits of breadth. Strateg. Manag. J. 2010, 31, 224-236. [CrossRef]

44. Gruner, K.E.; Homburg, C. Does customer interaction enhance new product success? J. Bus. Res. 2000, 49, 1-14. [CrossRef]

45. Van Aken, J.E.; Weggeman, M.P. Managing learning in informal innovation networks: Overcoming the Daphne-dilemma. R D Manag. 2000, 30, 139-150. [CrossRef]

46. Pyka, A. Informal networking and industrial life cycles. Technovation 2000, 20, 25-35. [CrossRef]

47. Mina, A.; Bascavusoglu-Moreau, E.; Hughes, A. Open service innovation and the firm's search for external knowledge. Res. Policy 2014, 43, 853-866. [CrossRef]

48. Dahl, M.S.; Pedersen, C.Ø. Knowledge flows through informal contacts in industrial clusters: Myth or reality? Res. Policy 2004, 33, 1673-1686. [CrossRef]

49. Seidler-de Alwis, R.; Hartmann, E. The use of tacit knowledge within innovative companies: Knowledge management in innovative enterprises. J. Knowl. Manag. 2008, 12. [CrossRef]

50. Howells, J. Tacit knowledge. Technol. Anal. Strateg. Manag. 1998, 2, 91-106. [CrossRef]

51. Leonard, D.; Sensiper, S. The role of tacit knowledge in group innovation. Calif. Manag. Rev. 1998, 40, $112-132$. [CrossRef]

52. Cavusgil, S.T.; Calantone, R.J.; Zhao, Y. Tacit knowledge transfer and firm innovation capability. J. Bus. Ind. Mark. 2003, 18, 6-21. [CrossRef]

53. Crescenzi, R.; Nathan, M.; Rodríguez-Pose, A. Do inventors talk to strangers? On proximity and collaborative knowledge creation. Res. Policy 2016, 45, 177-194. [CrossRef]

54. Martin, D.; Romero, I.; Wegner, D. Individual, organizational, and institutional determinants of formal and informal inter-firm cooperation in SMEs. J. Small Bus. Manag. 2019, 57, 1698-1711. [CrossRef]

55. Terjesen, S.; Patel, P.C. In search of process innovations: The role of search depth, search breadth, and the industry environment. J. Manag. 2017, 43, 1421-1446. [CrossRef]

56. Kreiner, K.; Schultz, M. Informal collaboration in R\&D. The formation of networks across organizations. Organ. Stud. 1993, 14, 189-209.

57. Schrader, S. Informal technology transfer between firms: Cooperation through information trading. Res. Policy 1991, 20, 153-170. [CrossRef]

58. Almeida, P.; Kogut, B. Localization of knowledge and the mobility of engineers in regional networks. Manag. Sci. 1999, 45, 905-917. [CrossRef]

59. Gulati, R. Alliances and networks. Strateg. Manag. J. 1998, 19, 293-317. [CrossRef]

60. Miller, D. The correlates of entrepreneurship in three types of firms. Manag. Sci. 1983, 29, 770-791. [CrossRef]

61. Covin, J.G.; Lumpkin, G.T. Entrepreneurial orientation theory and research: Reflections on a needed construct. Entrep. Theory Pract. 2011, 35, 855-872. [CrossRef]

62. Sadler-Smith, E.; Hampson, Y.; Chaston, I.; Badger, B. Managerial behavior, entrepreneurial style, and small firm performance. J. Small Bus. Manag. 2003, 41, 47-67. [CrossRef]

63. Keil, T.; Maula, M.; Syrigos, E. CEO entrepreneurial orientation, entrenchment, and firm value creation. Entrep. Theory Pract. 2017, 41, 475-504. [CrossRef]

64. Covin, J.G.; Miles, M.P. Corporate entrepreneurship and the pursuit of competitive advantage. Entrep. Theory Pract. 1999, 23, 47-63. [CrossRef]

65. Crescenzi, R.; Gagliardi, L. The innovative performance of firms in heterogeneous environments: The interplay between external knowledge and internal absorptive capacities. Res. Policy 2018, 47, 782-795. [CrossRef]

66. Donbesuur, F.; Boso, N.; Hultman, M. The effect of entrepreneurial orientation on new venture performance: Contingency roles of entrepreneurial actions. J. Bus. Res. 2020, 118, 150-161. [CrossRef]

67. Wiklund, J.; Shepherd, D. Entrepreneurial orientation and small business performance: A configurational approach. J. Bus. Ventur. 2005, 20, 71-91. [CrossRef]

68. Suchman, M.C. Managing legitimacy: Strategic and institutional approaches. Acad. Manag. Rev. 1995, 20, 571-610. [CrossRef]

69. Ma, H.; Guo, H.; Shen, R. Organisational regulatory legitimacy, entrepreneurial orientation, and SME innovation: An optimal distinctiveness perspective. Technol. Anal. Strateg. Manag. 2019, 31, 833-847. [CrossRef] 
70. Desai, V.M. Collaborative stakeholder engagement: An integration between theories of organizational legitimacy and learning. Acad. Manag. J. 2018, 61, 220-244. [CrossRef]

71. Hu, B.; Zhang, T.; Yan, S. How corporate social responsibility influences business model innovation: The mediating role of organizational legitimacy. Sustainability 2020, 12, 2667. [CrossRef]

72. Wong, A.; Fang, S.S.; Tjosvold, D. Developing business trust in government through resource exchange in China. Asia Pac. J. Manag. 2012, 29, 1027-1043. [CrossRef]

73. Dowling, J.; Pfeffer, J. Organizational legitimacy: Social values and organizational behavior. Pac. Sociol. Rev. 1975, 18, 122-136. [CrossRef]

74. Chen, Y.H.; Lin, T.P.; Yen, D.C. How to facilitate inter-organizational knowledge sharing: The impact of trust. Inf. Manag. 2014, 51, 568-578. [CrossRef]

75. Williamson, I.O. Employer legitimacy and recruitment success in small businesses. Entrep. Theory Pract. 2000, 25, 27-42. [CrossRef]

76. Bell, G.G. Clusters, networks, and firm innovativeness. Strateg. Manag. J. 2005, 26, 287-295. [CrossRef]

77. Ahn, J.M.; Minshall, T.; Mortara, L. Open innovation: A new classification and its impact on firm performance in innovative SMEs. Eur. J. Innov. Manag. 2015, 3, 33-54. [CrossRef]

78. Wang, C.L. Entrepreneurial orientation, learning orientation, and firm performance. Entrep. Theory Pract. 2008, 32, 635-657. [CrossRef]

79. Elsbach, K.D. Managing organizational legitimacy in the California cattle industry: The construction and effectiveness of verbal accounts. Adm. Sci. Q. 1994, 39, 57-88. [CrossRef]

80. Certo, S.T.; Hodge, F. Top management team prestige and organizational legitimacy: An examination of investor perceptions. J. Manag. Issues 2007, 19, 461-477.

81. Jansen, J.J.; Van Den Bosch, F.A.; Volberda, H.W. Exploratory innovation, exploitative innovation, and performance: Effects of organizational antecedents and environmental moderators. Manag. Sci. 2006, 52, 1661-1674. [CrossRef]

82. Anderson, J.C.; Gerbing, D.W. Structural equation modeling in practice: A review and recommended two-step approach. Psychol. Bull. 1988, 103, 411-423. [CrossRef]

83. Podsakoff, P.M.; MacKenzie, S.B.; Lee, J.Y.; Podsakoff, N.P. Common method biases in behavioral research: A critical review of the literature and recommended remedies. J. Appl. Psychol. 2003, 88, 879-903. [CrossRef]

84. Zhu, X.; Xiao, Z.; Dong, M.C. The fit between firms' open innovation and business model for new product development speed: A contingent perspective. Technovation 2019, 13, 86-87. [CrossRef]

85. Aiken, L.S.; West, S.G.; Reno, R.R. Multiple Regression: Testing and Interpreting Interactions; Sage Publications: London, UK, 1991.

86. Laursen, K.; Salter, A. Open for innovation: The role of openness in explaining innovation performance among UK manufacturing firms. Strateg. Manag. J. 2006, 27, 131-150. [CrossRef]

87. Gulati, R. Does familiarity breed trust? The implications of repeated ties for contractual choice in alliances. Acad. Manag. J. 1995, 38, 85-112.

88. Ahn, J.M.; Minshall, T.; Mortara, L. Understanding the human side of openness: The fit between open innovation modes and CEO characteristics. $R$ D Manag. 2017, 47, 727-740. [CrossRef]

89. Martínez-Costa, M.; Choi, T.Y.; Martínez, J.A.; Martínez-Lorente, A.R. ISO 9000/1994, ISO 9001/2000 and TQM: The performance debate revisited. J. Oper. Manag. 2009, 27, 495-511. [CrossRef]

90. Hochleitner, F.P.; Arbussà, A.; Coenders, G. Inbound open innovation in SMEs: Indicators, non-financial outcomes and entry-timing. Technol. Anal. Strateg. Manag. 2017, 29, 204-218. [CrossRef]

Publisher's Note: MDPI stays neutral with regard to jurisdictional claims in published maps and institutional affiliations.

(C) 2020 by the authors. Licensee MDPI, Basel, Switzerland. This article is an open access article distributed under the terms and conditions of the Creative Commons Attribution (CC BY) license (http://creativecommons.org/licenses/by/4.0/). 